\title{
Entrepreneurial Conative Component of Competences: the Case of Slovenia
}

\author{
Darko Kovač ${ }^{\star}$ Maja Meško', Andrej Bertoncelj2 \\ 1University of Primorska, Faculty of Management, maja.mesko@fm-kp.si \\ 2University of Primorska, Faculty of Management, andrej.bertoncelj@fm-kp.si
}

\begin{abstract}
Competitive pressures, globalization and economic growth have brought Slovenian enterprises to enhance the role of entrepreneurial competences. The present paper aims to study conative component of entrepreneurial competences as a crucial part of human capital in Slovenian enterprises. The focus of this paper is any eventual disparity of non-teachable attributes of conative component of competences of Slovene enterpreneuer with learned ones rather than the concept of entrepreneurship itself. Authors seperate entrepreneurial competences into three components: cognitive, affective and conative. The purpose of this study is to assess the entrepreneurial conative traits and to investigate the correlation between different conative components of entrepreneurial competences and compare the results to their job-related self-expetations. The conative component of entrepreneurial competences was measures with the Kolbe $\mathrm{A}^{\mathrm{TM}}$ Index. The study was conducted with 43 Slovenian entrepreneuers from three different enterprises. Independet sample t-test and Pearson's correlation were used to test research aims. SPSS 16.0 was used to analyse the data. The results show conative components of Slovenian entrepreneurial competences, difference between them and individual's job-related self expectations and that the correlation between conative components exist.
\end{abstract}

Key words: Entrepreneurship, conative entrepreneurial competences, Kolbe $A^{\text {TM }}$ Index, Kolbe $B^{\text {TM }}$ Index, Slovenia.

\section{Introduction}

Entrepreneurship has been associated with human beings since ancient times. People are innovative, willing to take risks and grasp opportunities in all areas of human activity (Schumpeter, 1971; Miller, 1983; Bird, 1989; Covin and Slevin, 1991; Kanungo, 1999; Drucker 1994; Bontis and Fitz-enz, 2002; Bertoncelj and Kovač, 2008). Entrepreneurial traits develop through the process of socialization, first in the family, later on in school, and then at work and through other forms of social encounters. Some people develop entrepreneurial traits in spite of unfavourable social conditions and others do not. It is argued that these individuals have some special traits or inner urge which, in combination with other extrinsic factors, result in entrepreneurial activity. Besides exogenous factors, i.e. the social, cultural and economic environment, and endogenous factors, i.e. relationships within an organization, also individual factors, have an influence on the organizational capacity of learning, learning outcomes and corporate performance. It is argued that this is even more important in post-transition economies, because they face, after market liberalization, many previously unknown challenges of increased competi- tion and unprecedented changes in cultural and social life (Barrow, 1998; Drejer and Riis, 1999; Beaver and Jennings, 2000; Kaplan, 2003; Bolton and Thompson, 2003).

The purpose of this paper is to develop a better understanding of entrepreneurial traits in Slovenia. It is focused on the individual factors of entrepreneurs, rather than the concept of entrepreneurship itself. Non-teachable attributes of entrepreneurs embedded in the conative component of competences are investigated and the 3 component model of competences is introduced (see Figure 1).

The paper is structured as follows: first the conceptual basis that guides the study is established and then it is tested empirically on a sample of companies. Finally, the results are discussed, pointing out the main limitations of the study and indicating possible future lines of research.

\subsection{Objectives of this study}

The main objective of the study is to assess the entrepreneurial traits which can be understood as inborn ones and are attributed to entrepreneurs. Therefore, the traits of entrepreneuers in Slovenian small and medium sized enterprises are studied.

\footnotetext{
*In memoriam: We would like to dedicate this paper to Darko Kovač (1957-2009), who tragically passed away shortly after the completion of this work.
} 
Moreover, a model of entrepreneurial competences based on the tripartite dichotomy of the mind is built: the cognitive component of entrepreneurial competences, the affective component of entrepreneurial competences, and the conative component of entrepreneurial competences.

The present study investigates the conative component of competences of entrepreneuers in the sample, which is measured with the Kolbe $A^{\mathrm{TM}}$ Index. The results are compared to their job-related self-expectations as measured by the Kolbe $\mathrm{B}^{\mathrm{TM}}$ Index.

To achieve the main objective, the study attempts to seek answers to the following hypotheses:

H1: There is a difference between the conative component of entrepreneurial competences and an individual's jobrelated self-expectations.

H2: There is the negative correlation between the conative components of entrepreneurial competences.

\section{Entrepreneurial competences}

Moving from capital and natural resources to human capital is an advantage in the globalization era. Thus, making effective use of human capital in the form of entrepreneurial competences become crucial in a competitive environment (Deborah and Ofori, 2005). Defining the very essence of entrepreneurship is not clear-cut; relevant literature perceives entrepreneurship, entrepreneurs, and business owners as aspects which can not be polarized, and should be more broadly conceived (Carland et al., 1984; Siropolis, 1990; Biloslavo and Trnavčevič, 2009). According to Zhao (2001), entrepreneurs use innovation to expand business scope and boost growth. Due to these reasons, entrepreneurship and innovation are dynamic and holistic processes that are not confined to the initial stage of a new venture (Herbig et al., 1994). Innovative spirit is the quintessence of entrepreneurship and the most basic quality requirement of modern enterprise (Drucker, 1985). Though risk tolerance is an expected trait of entrepreneurs, some scholars (Low and MacMillan, 1988; Shaver and Scott, 1991) do not see it as a characteristic of entrepreneurs.

Entrepreneuers, according to Sunbul and Yilmaz (2009) tend to identify market opportunity and exploit it by organizing their resources effectively to accomplish an outcome that changes existing interactions within a given sector. Enterpreneuer is the person who sizes the opportunities and takes risks by bringing the production factors such as labor technology, capital, and natural resources together to produce goods and services.

The research of entrepreneurial traits has a long tradition; however, the issue of whether entrepreneurship can be taught or if an entrepreneur is simply born remains open. Many scholars argue that at least some elements associated with the subject can be developed and enhanced through education and training (Kantor, 1988; Henry et al., 2005a; Kuratko, 2005; Henionen and Akola, 2007) and some elements are inborn (Henry et al. 2005b; Kuratko 2005; Jack and Anderson 1999; Kovač and Bertoncelj, 2008). According to other scholars (Shepherd and Douglas, 1996; Jack and Anderson, 1998; Ruzzier et al., 2007) entrepreneurship education incorporates teachable elements (the science of entrepreneurship) and nonteachable elements (the art of entrepreneurship). The art of entrepreneurship is usually not taught in schools; it is rather learned in the business environment through experience.

In entrepreneurial learning, the personal differences in ability which produce different learning outcomes as well as social and organisational differences (Corbett, 2005) have to be considered. It is argued that there are also close connections between the processes of entrepreneurial learning with those of opportunity recognition (Dutta and Crossan, 2005), exploitation, creativity, and innovation (Lumpkin and Lichtenstein, 2005).

\subsection{Conative component of entrepreneurial competences}

On the individual level, the science and art of entrepreneurship can be reflected in the concept of competences as an underlying characteristic of an individual. The attitudes and values necessary for ensuring an individual's commitment and identification with work are becoming more important. Without such a commitment, much of the learning, especially at the group level, can not take place (Ashton, 1998).

The competence concept has been investigated by many authors (Ellström, 1997; Ulrich, 1998; Mansfield, 1999; Miller et al., 2001; Jacobs and Pons, 1993; Deakins and Freel, 1998). Miller et al. (2001) divide competences into behavioural (soft) competences - how people should behave to complete work successfully - and technical or functional (hard) competences what people should know and are able to do to complete work successfully. In other words, soft competences explore the behavioural side of the mind and hard competences explore the cognitive side of the mind. In hard competences, skills and knowledge are combined. In soft competences, the behavioural aspect is added. However, the level of consensus among scholars (Jacobs and Pons, 1993; Deakins and Freel, 1998) who define the competences of entrepreneurs and small business owners, and specify the functional competences required for success, remains low.

We argue that entrepreneurial competence has different components; besides the soft component of competences (the affection side of the mind) and the hard component of competences (the cognitive side of the mind), the conative component of competences (the conative side of the mind) should be included into the concept. The conative side of entrepreneurial competences was omitted in the early research because the concept of behaviourism and cognition prevailed in the mid20th century. Several scholars (Snow, Corno and Jackson, 1996; Huit 1999; Kolbe, 1997) have renewed interest in the concept of the tripartite theory of the mind. Moreover, extracting the conative component of competences from cognitive and behavioural ones can help to explain not only the "source of actions in your deep inner nature, but also shows you how to build on those strengths" (Kolbe, 1997, 4). Kolbe (1997) claims that human beings have a conative style, or a preferred method of putting thought into action or interacting with the environment, which is separated from a person's intelligence or personality type. 
We argue further that the conative component of entrepreneurial competences comprises the most stable human competences, meaning that they are inborn, almost instinctive. Compared with the hard (cognitive) component of competences and soft (behavioural, affective) component of competences, which can be learned, the conative component of entrepreneurial competences can only be fostered. Some authors seemingly talk about genetic inheritance (Hudson, 1993), talent (Bontis and Fitz-enz, 2002), valuable and unique talents (Chen and Lin, 2004), and general employee sentiment (Bontis and Fitz-enz, 2002).

Conation is closely connected with the concept of volition, defined as the use of will, or the freedom to make choices about what to do (Kane, 1985). Some authors define conation as a proactive aspect of behaviour (as opposed to reactive or habitual), which is the personal, intentional, planful, deliberate, goal-oriented, or striving component of motivation (Baumeister et al., 1998; Emmons, 1986), or as the tendency to take purposive action toward goals (Snow, Corno and Jackson, 1996).

Based on Kolbe (2004), we can cluster the conative component of entrepreneurial competences into four groups:

- Component of competence to analyse, to justify;

- Component of competence to plan, to follow procedures;

- Component of competence to spot opportunities, to risk, to innovate;

- Component of competence to dexterity, to craftsmanship.
Kolbe (1997) suggests that human beings have a conative style, or a preferred method of putting thought into action or interacting with the environment. It is our knack of getting things done, the achievement aspect of ability, and the process through which we fulfil our goals.

\section{Research methodology}

In this section, the research methodology, data of analyses and discussion are presented. For the purpose of this study, a sample of three Slovene companies is used. Slovenia was chosen since it is a recent member of the EU which is still carrying out the transition to a free market through liberalization, stabilization, restructuring, and privatisation.

\subsection{Participants of the study}

For the purpose of this study, a sample of three randomly selected Slovenian SME companies is used. Our sample consisted of 43 top and middle managers, of whom $20.9 \%$ were female and $79.1 \%$ were male respondents. At the time of our study, $69.8 \%$ were over 30 years of age, $44.2 \%$ had more than 10 years of work experience and $30.2 \%$ had a university education. The sample is presented in Table 1.

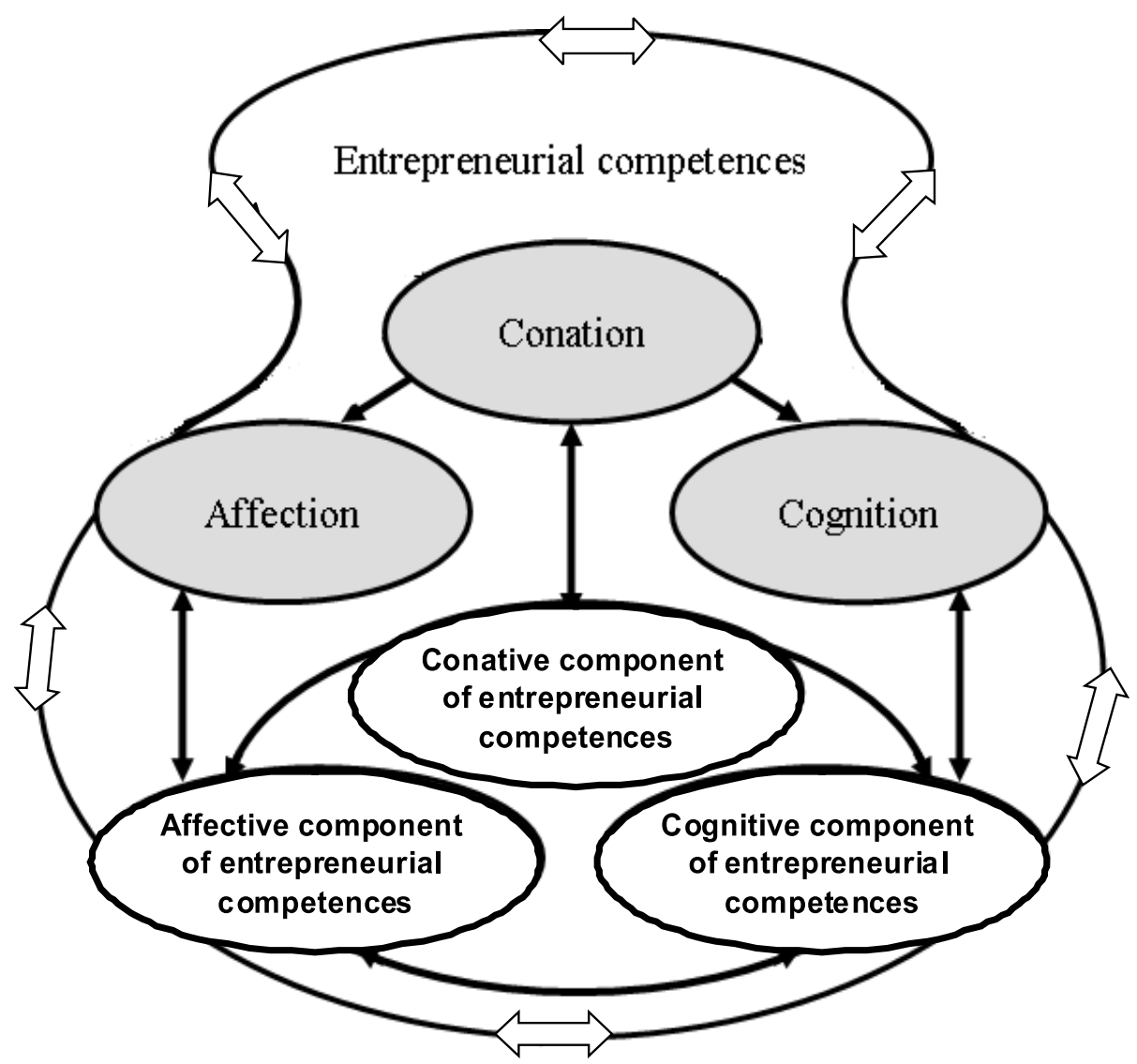

Figure 1: Framework model of three components of entrepreneurial competences 
Table 1: Sample composition

\begin{tabular}{|c|c|c|c|c|c|c|c|c|}
\hline \multirow[b]{3}{*}{ Sample size } & \multicolumn{2}{|c|}{ Company 1} & \multicolumn{2}{|c|}{ Company 2} & \multicolumn{2}{|c|}{ Company 3} & \multicolumn{2}{|c|}{ Total } \\
\hline & \multicolumn{2}{|l|}{ No. } & \multicolumn{2}{|c|}{ No. } & \multicolumn{2}{|c|}{ No. } & \multicolumn{2}{|l|}{ No. } \\
\hline & 28 & $100 \%$ & 8 & $100 \%$ & 7 & $100 \%$ & 43 & $100 \%$ \\
\hline \multicolumn{9}{|l|}{ Prior education level } \\
\hline Secondary/high school & 22 & $78,6 \%$ & 8 & $100 \%$ & 0 & $0,0 \%$ & 30 & $69,8 \%$ \\
\hline College/university & 6 & $21,4 \%$ & 0 & $0,0 \%$ & 7 & $100,0 \%$ & 13 & $30,2 \%$ \\
\hline \multicolumn{9}{|l|}{ Work experience } \\
\hline 10 years or less & 13 & $46,4 \%$ & 5 & $62,5 \%$ & 6 & $85,7 \%$ & 24 & $55,8 \%$ \\
\hline Over 10 years & 15 & $53,6 \%$ & 3 & $37,5 \%$ & 1 & $14,3 \%$ & 19 & $44,2 \%$ \\
\hline \multicolumn{9}{|l|}{ Age } \\
\hline 30 years or less & 8 & $28,6 \%$ & 4 & $50,0 \%$ & 1 & $14,3 \%$ & 13 & $30,2 \%$ \\
\hline Over 30 years & 20 & $71,4 \%$ & 4 & $50,0 \%$ & 6 & $85,7 \%$ & 30 & $69,8 \%$ \\
\hline \multicolumn{9}{|l|}{ Gender } \\
\hline Female & 4 & $14,3 \%$ & 2 & $25,0 \%$ & 3 & $42,9 \%$ & 9 & $20,9 \%$ \\
\hline Male & 24 & $85,7 \%$ & 6 & $75,0 \%$ & 4 & $57,1 \%$ & 34 & $79,1 \%$ \\
\hline
\end{tabular}

The companies in the sample were chosen in a random manner in different sectors of industry:

- Company 1: Engineering and related technical consultancy.

- Company 2: Cutting, shaping and finishing of ornamental and building stone.

- Company 3: Legal, accounting and market research.

\subsection{Instruments of the study}

The Kolbe A ${ }^{\mathrm{TM}}$ Index, which is, according to Kolbe (2003), a reliable and valid tool in terms of test-retest ${ }^{1,2}$, was used. Kolbe (2004) identifies four action or conative modes (Kolbe Action Modes ${ }^{\circledR}$ ) through which we act with different intensities and can be determined with the Kolbe $\mathrm{A}^{\mathrm{TM}}$ Index (conative reality):

- FF - Fact Finder, which is based on the instinctive need to probe and relates to the way we gather information.;

- FT - Follow Thru, which is based on the instinctive need to form patterns and deals with the way we organize information;

- QS - Quick Start, which is based on the instinctive need to innovate and how we deal with unknowns;

- IM - Implementer, which is based on the instinctive need to demonstrate and relates to the way we seek tangible solutions.

The degree of intensity each individual has in an action mode (Kolbe Action Mode ${ }^{\circledR}$ ) is defined on a scale from 1 to 10 with 10 being the most intense (Kolbe, 1997) ${ }^{3}$. Each mode has three zones of operation on a scale of 1 to 10 (Kolbe Corporation, 2004). In the Preventive zone (1 to 3), one prevents problems; in the Responsive zone (4 to 6), one acts in an accommodating way; and in the Initiative zone (7 to 10), one initiates solutions. The mentioned action modes are good indicators of conative competences. The Quick Start action mode is, according to the aforementioned personal traits of entrepreneurs and according to our opinion, especially close to conative component of entrepreneurial competences. The Kolbe $\mathrm{A}^{\mathrm{TM}}$ Index has become popular for different business applications, such as career development, interpersonal relationship management, personnel selection, team management, consulting and training (Wongchai, 2003). It could be claimed that inborn competences are measured with the Kolbe $\mathrm{A}^{\mathrm{TM}}$ Index.

Possible conflicts can be studied by comparing the Kolbe $\mathrm{A}^{\mathrm{TM}}$ Index results of different individuals with those individuals with different instincts that cross each other's progress by insisting on their own paths to problem solving. Kolbe claims that there will be stress between people working directly with one another if they have a difference of 4 or more in any mode (Kolbe, 1997). Comparing Kolbe $\mathrm{A}^{\mathrm{TM}}$ Index results to Kolbe $\mathrm{B}^{\mathrm{TM}}$ Index results (an individual's job-related selfexpectations) reveals strain on the job. Strain occurs when an individual tries to live up to false self-expectations (Kolbe, 1997). According to the Kolbe Corporation, there is no bias in gender, age, race, or national origin in Kolbe instrument results (Kolbe Corporation, 2004).

\subsection{Procedure}

The data were collected during the spring and summer of 2008 at different locations in Slovenia. The participants in this research completed Kolbe tests in a classroom, following the 
Table 2: Conative component of entrepreneurial competences measured by Kolbe $A^{\mathrm{TM}}$ Index

\begin{tabular}{|l|l|l|l|l|l|}
\hline Company & & FFa & FTa & QSa & IMa \\
\hline \multirow{3}{*}{ Company 1 } & Mean & 5.440 & 5.240 & 4.520 & 5.080 \\
\cline { 2 - 6 } & Std. Deviation & 1.609 & 1.362 & 1.686 & 1.730 \\
\hline \multirow{2}{*}{ Company 2 } & Mean & 5.857 & 4.714 & 4.142 & 5.285 \\
\cline { 2 - 6 } & Std. Deviation & 1.069 & 0.951 & 0.899 & 1.889 \\
\hline \multirow{3}{*}{ Company 3 } & Mean & 6.142 & 5.142 & 5.571 & 3.857 \\
\cline { 2 - 6 } & Std. Deviation & 1.069 & 1.573 & 1.718 & 0.899 \\
\hline \multirow{2}{*}{ Total } & Mean & 5.641 & 5.128 & 4.641 & 4.897 \\
\hline
\end{tabular}

instructions specified on the inventory. There was no time limit determined to complete the inventory.

The data were processed using the following methods:

- calculation of basic statistical parameters (descriptives);

- t-test; and

- Pearson's correlation coefficients.

All hypotheses were verified at a 5\% risk level $(\mathrm{p}=$ 0.05). The SPSS software package 16.0 was used for the data analysis.

\section{Data analyses}

Conative entrepreneurial traits were measured. The results are presented in Table 2.
The differences between the conative component of entrepreneurial competences and an individual's job-related self-expectations were examined with a Paired Samples t-test (see Table 3).

It could be confirmed that differences exist between the conative component of entrepreneurial competences and an individual's job-related self-expectations in the FF and FT conative mode, which was verified with a parametric and nonparametric test $(\mathrm{p}<0.05)$ in Company 1 . In Company 2, the difference could be statistically confirmed only in the FF conative mode $(\mathrm{p}<0.05)$ and for Company 3 in the FT conative mode $(\mathrm{p}<0.05)$.

Table 3 shows that the differences between the conative component of entrepreneurial competences and an individual's

Table 3: Paired Samples t test

\begin{tabular}{|c|c|c|c|c|c|c|c|c|c|c|}
\hline \multirow{3}{*}{ Company } & & & \multicolumn{5}{|c|}{ Paired Differences } & \multirow{3}{*}{$\mathrm{t}$} & \multirow{3}{*}{$\mathrm{df}$} & \multirow{3}{*}{$\begin{array}{c}\text { Sig. } \\
\text { 2-tailed }\end{array}$} \\
\hline & & & \multirow[t]{2}{*}{ Mean } & \multirow[t]{2}{*}{$\begin{array}{l}\text { Std. } \\
\text { Dev. }\end{array}$} & \multirow{2}{*}{$\begin{array}{l}\text { Std. } \\
\text { Error } \\
\text { Mean }\end{array}$} & \multicolumn{2}{|c|}{$\begin{array}{l}\text { 95\% Confidence } \\
\text { Interval of the } \\
\text { Difference }\end{array}$} & & & \\
\hline & & & & & & Lower & Upper & & & \\
\hline \multirow{4}{*}{ Company 1} & Pair 1 & $\mathrm{FFa}-\mathrm{FFb}$ & 0.84 & 1.70 & 0.34 & 0.13 & 1.54 & 2.47 & 24 & 0.021 \\
\hline & Pair 2 & $\mathrm{FTa}-\mathrm{FTb}$ & -1.28 & 1.79 & 0.35 & -2.01 & -0.54 & -3.57 & 24 & 0.002 \\
\hline & Pair 3 & QSa - QSb & 0.24 & 1.66 & 0.33 & -0.44 & 0.92 & 0.72 & 24 & 0.478 \\
\hline & Pair 4 & $\mathrm{IMa}-\mathrm{IMb}$ & 0.36 & 1.95 & 0.39 & -0.44 & 1.16 & 0.92 & 24 & 0.366 \\
\hline \multirow{4}{*}{ Company 2} & Pair 1 & $\mathrm{FFa}-\mathrm{FFb}$ & 2.14 & 1.46 & 0.55 & 0.78 & 3.49 & 3.87 & 6 & 0.008 \\
\hline & Pair 2 & $\mathrm{FTa}-\mathrm{FTb}$ & -0.71 & 1.49 & 0.56 & -2.09 & 0.66 & -1.26 & 6 & 0.253 \\
\hline & Pair 3 & $\mathrm{QSa}-\mathrm{QSb}$ & -0.40 & 1.81 & 0.68 & -2.10 & 1.24 & -0.63 & 6 & 0.555 \\
\hline & Pair 4 & IMa - IMb & -1.00 & 1.41 & 0.53 & -2.30 & 0.30 & -1.87 & 6 & 0.111 \\
\hline \multirow{4}{*}{ Company 3} & Pair 1 & $\mathrm{FFa}-\mathrm{FFb}$ & 1.14 & 1.57 & 0.59 & -0.31 & 2.59 & 1.92 & 6 & 0.103 \\
\hline & Pair 2 & $\mathrm{FTa}-\mathrm{FTb}$ & -1.42 & 1.51 & 0.57 & -2.82 & -0.03 & -2.50 & 6 & 0.047 \\
\hline & Pair 3 & $\mathrm{QSa}$ - QSb & -0.14 & 1.95 & 0.73 & -1.94 & 1.66 & -0.19 & 6 & 0.853 \\
\hline & Pair 4 & $\mathrm{IMa}-\mathrm{IMb}$ & 0.57 & 1.71 & 0.64 & -1.01 & 2.16 & 0.88 & 6 & 0.413 \\
\hline
\end{tabular}


job-related self-expectations are the largest in Companies 2 and 3 .

It is characteristic of all three companies that the result for the conative component of entrepreneurial competences for the FF conative mode is higher than job-related self-expectations. For the FT conative mode just the opposite could be claimed. The result for the conative component of entrepreneurial competences for the QS conative mode is almost identical with that of job-related self-expectations. The same stands for the IM conative mode, except for Company 2, in which the result for the job-related self-expected one is higher than for the conative component of entrepreneurial competence. For Company 2 it could be claimed that the differences between the conative component of entrepreneurial competences and self-expected job competences are the highest (4.3 points, with the most expressed in the FF conative mode). The differences between the conative component of entrepreneurial competences and self-expected job competences in Company 3 is 3.3 points, with the most expressed in the FT conative mode. In Company 1, the harmonization between the conative component of entrepreneurial competences and self-expected job competences is the highest; the difference is 2.7 points.

The correlation of the conative component of entrepreneurial competences as measured with the Kolbe $\mathrm{A}^{\mathrm{TM}}$ Index in the whole sample, regardless of the company, was analysed. The results are shown in Table 4.

The FF conative mode is strongly negatively correlated with the IM conative mode $(\mathrm{r}=-0.493, \mathrm{p}<0.01)$, while a weak negative correlation between the QS conative mode and the FF conative mode can not be confirmed. It could be concluded that the higher result in the FF conative mode is due to the IM conative mode result. The FT conative mode is negatively correlated with the QS conative mode $(\mathrm{r}=-0.323, \mathrm{p}<0.05)$. The IM conative mode is weakly correlated with the FT conative mode, but the correlation can not be statistically confirmed
( $>0.05$ ). It could be concluded that the higher FT conative mode result correlates with the lower QS conative mode result. The QS conative mode is the most strongly correlated with the IM conative mode $(r=-0.44, p<0.01)$ and, as previously mentioned, with the FT conative mode $(\mathrm{r}=-0.323, \mathrm{p}<0.05)$. It could be concluded that the higher QS conative mode result correlates with the lower FT conative mode and IM conative mode result. For the IM conative mode result it could be claimed that the higher IM conative mode result correlates with the lower FF conative mode result and also with some lower QS conative mode results.

The correlation of individual job-related self-expected competences as measured with the Kolbe $\mathrm{B}^{\mathrm{TM}}$ Index in the whole sample, regardless of the company, is shown in Table 5.

The Kolbe $\mathrm{B}^{\mathrm{TM}}$ Index result for the job-related selfexpected FF conative mode is similar to the Kolbe $\mathrm{A}^{\mathrm{TM}}$ Index result for the conative component of entrepreneurial competences for the FF conative mode, as it is negatively correlated with IM $(\mathrm{r}=-0.351, \mathrm{p}<0.05)$. The Kolbe $\mathrm{B}^{\mathrm{TM}}$ Index result for the job-related self-expected FT conative mode is negatively correlated with the Kolbe $\mathrm{B}^{\mathrm{TM}}$ Index result for the job-related self-expected IM conative mode $(r=-0.392, p<0.05)$. A strong negative correlation exists between the Kolbe $\mathrm{B}^{\mathrm{TM}}$ Index result for the job-related self-expected QS conative mode and the Kolbe $\mathrm{B}^{\mathrm{TM}}$ Index result for the job-related self-expected IM conative mode $(r=-0.614, \mathrm{p}<0.01)$, meaning a higher result for the job-related self-expected QS conative mode, a lower one for the job-related self-expected IM conative mode, and vice versa.

\section{Findings and discussion}

The mentioned differences could be observed in all three sample companies. The mean result of the conative component

Table 4: Correlation between conative entrepreneurial competences measured by Kolbe A $^{\mathrm{TM}}$ Index

\begin{tabular}{|l|l|l|l|l|l|}
\hline & & FFa & FTa & QSa & IMa \\
\hline \multirow{5}{*}{ FFa } & Pearson Corr. & 1 & -0.003 & -0.272 & $-0.493(* *)$ \\
\cline { 2 - 6 } & Sig. (2-tailed) & - & 0.986 & 0.094 & 0.001 \\
\cline { 2 - 6 } & $\mathrm{n}$ & 39 & 39 & 39 & 39 \\
\hline \multirow{5}{*}{ FTa } & Pearson Corr. & -0.003 & 1 & $-0.323(*)$ & -0.302 \\
\cline { 2 - 6 } & Sig. (2-tailed) & 0.986 &. & 0.045 & 0.062 \\
\cline { 2 - 6 } & $\mathrm{n}$ & 39 & 39 & 39 & 39 \\
\hline \multirow{5}{*}{ IMa } & Pearson Corr. & -0.272 & $-0.323(*)$ & 1 & $-0.440(* *)$ \\
\cline { 2 - 6 } & Sig. (2-tailed) & 0.094 & 0.045 &. & 0.005 \\
\cline { 2 - 6 } & $\mathrm{n}$ & 39 & 39 & 39 & 39 \\
\hline & Pearson Corr. & $-0.493(* *)$ & -0.302 & $-0.440(* *)$ & 1 \\
\cline { 2 - 6 } & Sig. (2-tailed) & 0.001 & 0.062 & 0.005 &. \\
\cline { 2 - 6 } & $\mathrm{n}$ & 39 & 39 & 39 & 39 \\
\hline
\end{tabular}

* Correlation is significant at the 0.05 level (2-tailed).

** Correlation is significant at the 0.01 level (2-tailed). 
Table 5: Correlation of an individual's job-related self-expectations measured by Kolbe $B^{\mathrm{TM}}$ Index

\begin{tabular}{|c|c|c|c|c|c|}
\hline & & $\mathrm{FFb}$ & $\mathrm{FTb}$ & QSb & $\mathrm{IMb}$ \\
\hline \multirow{3}{*}{$\mathrm{FFb}$} & Pearson Corr. & 1 & 0.218 & -0.245 & $-0.351\left(^{*}\right)$ \\
\hline & Sig. (2-tailed) & . & 0.183 & 0.132 & 0.028 \\
\hline & $\mathrm{n}$ & 39 & 39 & 39 & 39 \\
\hline \multirow{3}{*}{ FTb } & Pearson Corr. & 0.218 & 1 & -0.287 & $-0.392(*)$ \\
\hline & Sig. (2-tailed) & 0.183 & . & 0.077 & 0.014 \\
\hline & $\mathrm{n}$ & 39 & 39 & 39 & 39 \\
\hline \multirow{3}{*}{ QSb } & Pearson Corr. & -0.245 & -0.287 & 1 & $-0.614(* *)$ \\
\hline & Sig. (2-tailed) & 0.132 & 0.077 & . & 0 \\
\hline & $\mathrm{n}$ & 39 & 39 & 39 & 39 \\
\hline \multirow{3}{*}{$\mathrm{IMb}$} & Pearson Corr. & $-0.351(*)$ & $-0.392(*)$ & $-0.614(* *)$ & 1 \\
\hline & Sig. (2-tailed) & 0.028 & 0.014 & 0 & . \\
\hline & $\mathrm{n}$ & 39 & 39 & 39 & 39 \\
\hline
\end{tabular}

* Correlation is significant at the 0.05 level (2-tailed).

** Correlation is significant at the 0.01 level (2-tailed).

of entrepreneurial competences for all four action modes for all three sample companies differs as well. The highest mean result in the FF conative mode is in Company 3, which could be attributed to the industry (legal, accounting, bookkeeping, market research, consultancy; holdings). Company 1 has the highest mean result in the FT conative mode. One of the reasons is probably the procedures that the company's employees have to follow in engineering activities. The mean result for the QS conative mode is the highest for Company 3. Again, we argue that the sector of industry influences the way in which employees with an inclination to invent, brainstorm, originate, devise, challenge, contrive, risk, play, reform, improvise, promote, and intuit are desired. At the same time, these personal traits are the most commonly enumerated personal traits that entrepreneurs should have. It comes as no surprise that the mean result in the IM conative mode is the highest in Company 2 due to its core business of cutting, shaping and finishing of ornamental and building stone. However, it can not be forgotten that the standard deviation is the highest in that company when comparing the IM conative mode of all three companies.

Hypothesis 1, which claims that a difference between the conative component of entrepreneurial competences and an individual's job-related self-expectations exist, is confirmed. Employees perceive job expectations somehow differently from their conative component of entrepreneurial competences. The difference in the FF conative mode is the highest in Company 2, meaning that employees can not foster their entrepreneurial component of competence to probe, research, formalize, allocate, deliberate, prioritise, define, prove, specify, calculate, inquire, and evaluate in such a way that would match their inborn potential. This could be attributed to the competitive situation in the industry and more demand for dexterity and craftsmanship than for analysing. Keeping in mind that the difference between the conative component of entrepreneurial competences and an individual's job-related self-expectations in the QS conative mode and IM conative mode is the highest also in Company 2, it could be concluded that more conative stress exists in Company 2 than in the other two companies. Quicker decisions, more risk, more invention and more creativity is expected from the employees in Company 2 than they naturally possess. Also, more tangible solutions, dexterity, and craftsmanship is expected from employees in Company 2 than they have, which is somehow expected due to the industry. The difference between the conative component of entrepreneurial competences and an individual's job-related self-expectations in the FT conative mode is the highest in Company 3, meaning that employees believe that they must follow procedures, budgets and plans more than they would according to their natural inclination. There is no doubt that the difference between the conative component of entrepreneurial competences and an individual's job-related self-expectations exist.

Hypothesis 2, which deals with the correlation between the conative component of entrepreneurial competences, meaning the more of one, the less of the other, is confirmed as well. This could lead us to the conclusion that the most commonly desired entrepreneurial personal traits, such as the inclination to invent, brainstorm, originate, devise, challenge, contrive, risk, play, reform, improvise, promote, and intuit, would be higher if other conative modes were lower. This could be an important observation for practitioners, and might be worthwhile to build on. The results are similar for an individual's job-related self-expectations.

We believe that besides the cognitive (hard) and behavioural (soft) components of entrepreneurial competences, the conative component of entrepreneurial competences is worth researching. Neglecting a preferred method of putting thought into action or interacting with the environment or someone's conative style might result in strain and, consequently, lower 
efficiency. With the conative component of competences we touch the innate, inborn side of competences.

The study suggests that the most emphasised specific conative traits, i.e. to invent, brainstorm, originate, devise, challenge, contrive, risk, play, reform, improvise, promote and intuit, are differently correlated with other personal traits, especially having in mind self-expected behaviour.

The different correlation in the conative component of entrepreneurial competences and an individual's job-related self-expectations also means that employees are adapting on behalf of their natural conative style. Sometimes they even hide their natural, inborn way of doing things. Consequently, they invest more energy to perform, with an important influence on their personal, and their company's, results.

The correlation of entrepreneurial competences in different companies would most probably be different. The question arises as to how to intrinsically motivate employees to exhibit their best natural talents in the way that they would achieve their professional aspirations and satisfaction, and on the other hand, that they would be effective and efficient in achieving companies' goals and objectives.

However, the results of the study suggest that the combination of the conative component of competences can have a different impact on individual companies. What matters in contemporary management practice is how hidden potentials are set free and how they intrinsically motivate employees according to their personal differences in capabilities. Hence, in day-to-day operations individual personal traits should be carefully considered.

\section{Conclusion and future research}

The results of the study show how the conative side of the mind, and thus the conative component of competences of Slovene entrepreneuer.. Individual responses to changes differ according to competences, especially conative ones. However, increasing complex demand and tasks in a globalised world, and the elevated need for entrepreneurship, require not only knowledge and skills (the cognitive component of entrepreneurial competences) as well as appropriate emotions and attitudes (the affective component of entrepreneurial competences) but also involves "preferred methods of putting thought into action or interacting with the environment" (Kolbe, 1997) or the conative component of entrepreneurial competences. All those components should be effectively managed and none should be neglected.

We argue that acquiring these competences is an ongoing, lifelong learning process. The cognitive component of competences can be learned and the affective component of competences can be acquired through the process of professional socialization. Contrary to that, the conative component of competences is inborn and can be only fostered.

Further longitudinal research to measure the level of adapting on the national level and to address the issue of causality, especially in transition economies, is needed. The discussed issue should be studied with increased care in Slovenia and in other transition economies due to its potential and as a possible way to catch up with more developed economies.

\section{References}

Ashton, D. (1998). Skills formation: redirecting the research agenda, IN: Coffield, F. (Ed.): Learning at Work, The Policy Press of Bristol, Bristol.

Baumeister, R., Bratslavsky, E., Muraven, M. \& Tice, D.M. (1998). Ego depletion: Is the active self a limited resource?, Journal of Personality and Social Psychology, 74(5):1252-1265.

Beaver, G. \& Jennings P.L. (2000). Small Business, Entrepreneurship and Enterprise Development, London, Financial Times/ Prentice Hall. DOI: 10.1002/1099-1697(200011)9:7<397::AIDJSC519>3.0.CO;2-P

Barrow, C. (1998). The Essence of Small Business, London, Prentice Hall Europe.

Bertoncelj, A. \& Kovač, D. (2008). The influence of management capital on enterprise performance. International journal of management and enterprise development, 5(4), 444-461. DOI: 10.1504/IJMED.2008.018761.

Biloslavo, R. \& Trnavčevič, A. (2009). Web sites as tools of communication of a "green" company. Management Decision, 47(7): 1158-1173. DOI: 10.1108/00251740910978359.

Bird, B. (1989). Entrepreneurial Behaviour, IL and London, Scott, Foresman, Glenview.

Bolton, B. \& Thompson, J. (2003). The Entrepreneurs in Focus: Achieve Your Potential, London, Thomson Learning.

Bontis, N. \& Fitz-enz, J. (2002). Intellectual capital ROI: a causal map of human capital antecedents and consequents, Journal of Intellectual Capital, 13 (3): 223-247. DOI: $10.1108 / 14691930210435589$.

Chen, H. M \& Lin, K. J. (2004). The role of human capital cost in accounting, Journal of Intellectual Capital, 5(1), 116-130. DOI: 10.1108/14691930410512950.

Corbett, A. C. (2005). Experiential learning within the process of opportunity identification and exploitation, Entrepreneurship: Theory and Practice, 29(4): 473-491. DOI: 10.1111/j.15406520.2005.00094.x.

Covin, J. G. \& Slevin, D. (1991). A conceptual model of entrepreneurship as firm behaviour, Entrepreneurship: Theory and Practice, 16(1): 7-25.

Deakins, D. \& Freel, M. (1998). Entrepreneurial Learning and the Growth Process in SMEs, The Learning Organization, 5(3): 144-155.

Debrah, Y. A. \& Ofori, G. (2005). Emerging managerial competencies of professionals in the Tanzanian construction industry. International Journal of Human Resource Management 16(8), 1399-1414. DOI: 10.1080/09585190500220465.

Drejer, A. \& Riis, J.O. (1999). Competence development and technology: How learning and technology can be meaningfully Integrated. Technovation, 19(10): 631-644. DOI: 10.1016/ S0166-4972(99)00064-4.

Drucker, P.F. (1994). Innovation and Entrepreneurship: Practice and Principles, London, Heinemann.

Drucker, P.F. (1985). Innovation and Entrepreneurship, New York, Harper and Row.

Dutta, D. K. \& Crossan, M. M. (2005). The nature of entrepreneurial opportunities: understanding the process using the organizational learning framework, Entrepreneurship: Theory and Practice, 29(4): 425-449. DOI: 10.1111/j.1540-6520.2005.00092.x

Ellström, P.E. (1997). Integrating learning and work: problems and prospects, Contribution to the FORUM Workshop: Learning in Learning Organizations, University of Evora, Evora.

Emmons, R. (1986). Personal strivings: an approach to personality and subjective well-being, Journal of Personality and Social Psychology, 51(5): 1058-1068. DOI: 10.1037/00223514.51.5.1058 
Henionen, J. \& Elisa Akola, E. (2007). Entrepreneurship training and entrepreneurial learning in Europe - results from entlearn project, Turku School of Economics, Turku. http://webct.tukkk. fi (7.5.2010).

Henry, C., Hill, F. \& Leitch, C. (2005a). Entrepreneurship education and training: can entrepreneurship be taught?, Part I, Education+Training, 47(2): 98-111. DOI: 10.1108/00400910510586524.

Henry, C., Hill, F. \& Leitch, C. (2005b). Entrepreneurship education and training: can entrepreneurship be taught?, Part II, Education+Training, 47(3): 158-169. DOI: 10.1108/00400910510592211.

Herbig, P., Golden E. J. \& Dunphy, A. (1994). The relationship of structure to entrepreneurial and innovative success, Marketing Intelligence \& Planning, 12(9): 37-48. DOI: 10.1108/02634509410069038

Hudson, W. (1993). Intellectual Capital: How to Build It, Enhance It, Use It, New York, John Wiley\&Sons.

Jack, S.L. \& Anderson, R. (1998). Entrepreneurship education within the condition of entreprenology, Proceedings of the Conference on Enterprise and Learning, Aberdeen.

Jack, S.L. \& Anderson, A.R. (1999). Entrepreneurship education within the enterprise culture, International Journal of Entrepreneurship Behavior \& Research, 5( 3): 110-125. DOI: 10.1108/13552559910284074

Jacobs, R. \& Pons, T. (1993). Developing a New Model of Individual and Team Competence in Small Business, Paper presented at the $16^{\text {th }}$ National Small Firms Policy and Research Conference, Nottingham.

Kane, R. (1985). Free will and values, Albany, State University of New York Press.

Kantor, J. (1988). Can entrepreneurship be taught? - A Canadian experiment, Journal of Small Business and Entrepreneurship, 5(4): 12-19.

Kanungo, R. N. (1999). Entrepreneurship and Innovation: Models for Development (Ed.), London Sage Publications.

Kaplan, J. (2003). Patterns of Entrepreneurship, Englewood Cliffs, John Wiley \& Sons.

Kolbe, K. (1997). The conative connection, Reading, AddisonWesley Publishing Company, Inc.

Kolbe Corporation. (2004). Kolbe Bottom Lines, Kolbe Corporation, Phoenix, Kolbe Corporation.

Kolbe, K. (2003). Kolbe Statistical Handbook, Phoenix, Kolbe Corporation. http://www.kolbe.com (17.5.2010).

Kuratko, D.F. (2005). The emergence of entrepreneurship education: development, trends, and challenges, Entrepreneurship: Theory and Practice, 29(5): 577-597. DOI: 10.1111/j.15406520.2005.00099.x.

Kovač, D. \& Bertoncelj, A. (2008). Organizational Mental Map and Conative Competences, Organizacija - Journal of Management, Informatics and Human Resources, 41 (4): 127-135. DOI: 10.2478/v10051-008-0014-6.

Lumpkin, G.T. \& Lichtenstein, B.B. (2005). The role of organizational learning in the opportunity-recognition process, Entrepreneurship: Theory and Practice, 29 (4): 451-472. DOI: 10.1111/j.1540-6520.2005.00093.x

Mansfield, B. (1999). What is "competence" all about?, Competency, 6 (3): 24-28.

Miller, D. (1983). The correlates of entrepreneurship in three types of firms, Management Science, 29 (7), 770-791. DOI: 10.1287/ mnsc.29.7.770.

Miller, E., Rankin, N. \& Neathey, F. (2001). Competency Frameworks in UK Organizations, London, CIPD.

Ruzzier, M., Antončič, B., Hisrich, R. D. \& Konečnik Ruzzier, M. (2007). Human capital and SME internationalization : a struc- tural equation modeling study, Can. j. adm. sci., 24 (1), 15-29. DOI: $10.1002 /$ cjas.3.

Schumpeter, J. A. (1971). The fundamental phenomenon of economic development, in Kilby, P. (Eds.), Enretpreneurship and economic development, New York, The Free Press.

Shepherd, D.A. \& Douglas, E.J. (1996). Is management education developing or killing the entrepreneurial spirit? IN: Conference proceedings of The Internationalising Entrepreneurship Education and Training Conference, Arnhem, 24-26 June, 1996.

Snow, R.E., Corno, L. \& Jackson, D. (1996). Individual differences in affective and conative functions, IN: Berlinger, D.C. and Calfee, R.C. (Eds.): Handbook of Educational Psychology, New York, Macmillan Reference Books.

Sunbul, A. M. \& Yilmaz, E. (2009). Developing Scale Of University Students Entrepreneuership. Selcuk Universitesi Sosyal Bilimler Enstitusu Dergisi, 21, 195-203.

Ulrich, D. (1998). Intellectual capital = competence X commitment, Sloan Management Review, 39: 15-30.

Wongchai, S. (2003). The ability of the Kolbe A Index action modes to predict learners' attitudes and achievements within a webbased training context, Ph. D. dissertation, College Station, Texas.

Zhao, F. (2001). Managing innovation and quality of collaborative $\mathrm{R} \& \mathrm{D}$ in conference proceedings of The 5th International \& 8th National Research Conference, Melbourne.

Darko Kovač (1957-2009), M.Sc., was a Lecturer at the Vocational College for Catering and Tourism Bled and Director of CO\&DA Ltd. Consultancy. He was an internationally recognized expert in the field of human capital measurement. He published several papers on human capital assessment in international journals.

Maja Meško is an Assistant Profesor at the University of Primorska, Faculty of Management Koper. Her main areas of research interest are human resources management, management, organizational culture, organizational social climate, and sports psychology. Her work has been published in international professional and scientific journals.

Andrej Bertoncelj is an Associate Professor and Associate Dean at the University of Primorska, Faculty of Management Koper. His main research areas are strategic management and human capital assessment. He received a silver award of recognition from GZS for co-development of the business model of four evolutionary phases.

\section{Appendix}

The validity of the Kolbe $\mathrm{A}^{\mathrm{TM}}$ Index was investigated. According to the Kolbe Corporation, the analysis which summarized eight studies on the relationship between participants' Action Modes and participants' performance measurements in various fields including sales, aerospace, construction, and insurance (Kolbe, 2003) was made. The Winer $\mathrm{Z}_{\mathrm{c}}$ was 14.35. Cohen's equation for the effect size where $d=$ effect size index for t-tests of means in standard units, $\mathrm{M}_{1}$ and $\mathrm{M}_{2}$ $=$ population means in original measurement units, and $\mathrm{r}=$ the 
standard deviation of either population, was used. Assuming the Kolbe A ${ }^{\mathrm{TM}}$ Index's use as a selection instrument, the effect size would be .67 . That is greater than 0.5 , which is considered significant (Kolbe Corporation, 2003). Therefore, this instrument was considered valid in predicting performance. However, the effect size of 0.67 means that only $45 \%\left(0.67^{2}\right)$ of performance variations which can be accounted for by the Kolbe $\mathrm{A}^{\mathrm{TM}}$ Index should be considered. The other $55 \%$ of the performance variations can still be attributed to other factors. The findings are summarized in Table I.Table I: Validity of the Kolbe A Index

\begin{tabular}{|l|l|l|l|l|l|}
\hline Study & $\mathrm{n}$ & $\mathrm{r}$ & $\mathrm{t}$ & $\mathrm{M} 1-\mathrm{M} 2$ & Significance \\
\hline A & 425 & .86 & 34.668 & 0.60 & $<0.01$ \\
\hline $\mathrm{B}$ & 30 & .90 & 10.925 & 0.84 & $<0.01$ \\
\hline C & 45 & .69 & 6.216 & 0.71 & $<0.01$ \\
\hline $\mathrm{D}$ & 39 & .95 & 18.502 & 0.64 & $<0.01$ \\
\hline E & 87 & .93 & 23.325 & 0.67 & $<0.01$ \\
\hline $\mathrm{F}$ & 39 & .81 & 8.402 & 0.75 & $<0.01$ \\
\hline $\mathrm{G}$ & 177 & .68 & 12.269 & 0.68 & $<0.01$ \\
\hline $\mathrm{H}$ & 50 & .58 & 4.934 & 0.68 & $<0.01$ \\
\hline
\end{tabular}

Winner $Z_{c}=41.35$

Cohen $E S=0.97$

Source: Kolbe Corporation, 2003.

Reliability has been assessed in terms of test-retest reliability (Kolbe, 2003). Seventy employees from two major corporations, a marketing management company and an economic development firm participated. Data were collected eight to fifteen months apart. According to the data, the correlation coefficients are considered statistically significant and the measurements of the four Action Modes consistent over time. The Pearson's correlation coefficients between two periods of time were summarized in Table II.

Table II: Reliability of the Kolbe A Index

\begin{tabular}{|l|l|}
\hline Mode & Coefficient \\
\hline Fact Finder & $\mathrm{p}=0.69$ \\
\hline Follow Thru & $\mathrm{p}=0.71$ \\
\hline Quick Start & $\mathrm{p}=0.85$ \\
\hline Implementer & $\mathrm{p}=0.77$ \\
\hline
\end{tabular}

Source: Kolbe Corporation, 2003.

With the following statements Kolbe describes an individual who scores highly in each action mode (7 to 10) as follows (Kolbe Corporation, 1999):

- Fact Finder $(F F)$ will most likely succeed at tasks which require an individual to: probe, research, formalize, allocate, deliberate, prioritise, define, prove, specify, calculate, inquire, and evaluate.

- Follow Thru (FT) will most likely succeed at tasks which require an individual to: structure, consolidate, translate, prepare, discipline, coordinate, arrange, integrate, schedule, plan, budget, and chart.

- Quick Start (QS) will most likely succeed at tasks which require an individual to: invent, brainstorm, originate, devise, challenge, contrive, risk, play, reform, improvise, promote, and intuit.

- Implementer (IM) will most likely succeed at tasks which require an individual to: form, mould, demonstrate, craft, shape, put together, build, render, construct, fix, repair, and practice. 